\title{
Prevalence of temporomandibular joint disorders and neck pain in musicians: a sytematic review
}

\author{
Prevalência de distúrbios da articulação temporomandibular e \\ cervicalgias em músicos instrumentistas: uma revisão sistemática
}

\author{
[a] Instituto Nacional do Esporte (INESP), Brasília, DF, Brazil \\ [b] Universidade de Brasília (UnB), Brasília, DF, Brazil
}

Bennatan Ferreira dos Santos ${ }^{[a]}$, Thaís Branquinho Oliveira Fragelli ${ }^{[b]^{*}}$

\begin{abstract}
Introduction: The instrumental practice for a long time, the high performance level, the strict technique and the specific shape of each musical instrument can take musicians to overcome their physiological limits, giving a high prevalence of musculoskeletal injuries. Objective: Investigate the prevalence of temporomandibular joint disorder and neck pain in musicians. Methods: Between August and September 2015 were reviewed five databases: LILACS, SciELO, Medline / PubMed, Scopus and Web of Science. The articles were read and evaluated by the criteria of the Strengthening the Reporting of Observational Studies in Epidemiology (STROBE), items, that obtained a percentage above of 50 percent, were considered in the analysis of this work. Results: 15 articles attended the inclusion criteria. Among all musicians the prevalence of TMJ pain ranged from $10-81 \%$ and the prevalence of neck pain ranged from 29 - 80\%. Conclusion: In this study was observed that the musicians showed both, temporomandibular joint disorders and neck pain, watching a high prevalence especially in violinists and the horn players. In the risk factors identified in the literature for the emergence of painful symptoms in musicians, stand out the biomechanical factors involved in maintaining anti-physiologic postures.
\end{abstract}

Keywords: Temporomandibular Joint Disorders. Epidemiology. Neck Pain. Music.

* BFS: BS, email: bennatanferreira@gmail.com

TBOF: PhD, email: thaisbranquinho@hotmail.com 
Resumo

Introdução: A prática instrumental por tempo prolongado, o alto grau de desempenho, a rigorosa técnica e o formato específico de cada instrumento musical podem levar os músicos a ultrapassarem seus limites fisiológicos, conferindo uma alta prevalência de lesões musculoesqueléticas. Objetivo: Investigar a prevalência de transtornos da articulação temporomandibular e de cervicalgia em músicos. Métodos: Entre agosto e setembro 2015 foram examinadas cinco bases de dados: LILACS, SciELO, MedLine/PubMed, Scopus e Web of Science. Os artigos foram lidos e avaliados pelos critérios do Strengthening the Reporting of Observational Studies in Epidemiology (STROBE), artigos que obtiveram um percentual acima de 50\% foram considerados na análise do presente trabalho. Resultados: Atenderam aos critérios de inclusão nesse estudo 15 artigos. Dentre todos os músicos a prevalência de dor na ATM variou de 10 - 81\% e a prevalência de cervicalgia variou de 29 - 80\%. Conclusão: No presente estudo pôde-se verificar que os músicos apresentam tanto DTM quanto cervicalgias, observando uma alta prevalência em especial os violinistas, os violistas e os instrumentistas de sopro. Entre os fatores de risco identificados na literatura para o surgimento de sintomas dolorosos em músicos destacam-se os fatores biomecânicos envolvidos na manutenção de posturas antifisiológicas.

Palavras-chave: Transtornos da Articulação Temporomandibular. Epidemiologia. Cervicalgia. Música.

\section{Introduction}

The term temporomandibular joint disorders (TMJD) is commonly used to describe a number of signs and symptoms that generate functional and pathologyc alterations involving the masticatory muscles, the temporomandibular joint (TMJ) and the whole stomatognathic system $(1-3)$. Among the main symptoms involved are: joint pain, limitation or asymmetry of the movements, noises in the TMJ, the increased tension of the masticatory muscles, muscle fatigue, headaches and wear occlusal associated with parafunctions as, for example, bruxism and dental tightening ( $4-7)$. This functional impairment associated with TMJD can cause anxiety, common to other chronic diseases patients, leading to negative effects on their life quality (LF) $(8-10)$.

Correlations are made about the existence of signs and symptoms of neck pain in TMJD patients, for postural cervical changes that alter the mandibular and condyle postures. Adding also that painful stimuli in the neck can lead to pain in the facial region. In this respect, the neck pain is multifactorial in origin and occurs frequently in the working population, especially in those who perform static postures tasks, for example, in raising the upper limbs $(11,12)$.

For music fans this is considered as an art and emotion expression, closely associated with the leisure and well-being, however, when evaluating the performative activity in musical instrument, the look on the music activity exercise as profession should be differentiated by checking that the activity requires productivity and high performance with both psychological as physical capabilities (13).

In this aspect, the instrumental practice for a long time, the high level of performance required, the individual strict technique and the specific format of each musical instrument can lead professionals, often to exceeding their physiological limit $(13,14)$. This fact associated with poor posture, constant muscle usage and the playing tendency, even in the presence of pain, exposes this population to the psychological and physical burden of considerable intensity, leading to the occurrence of so-called Repetitive Strain Injury / Musculoskeletal Disorders related to work (RSI / MSDs) as reported in the literature, among which includes neck pain and TMJD (13 - 17).

Studies show that the prevalence of RSI / MSDs, in general, is high revealing a public health problem, in addition, these dysfunctions have increasingly earlier appeared in life professionals (16). The impact is not only in the quality of life decreasing, but also in the fact that these disorders can lead to early closure of their careers (16).

Understanding that the musician activity is a working line and as such can bring physical and psychological overload documented in the literature is that the present study aimed to investigate 
the prevalence of temporomandibular disorder and neck pain in musicians, as what is noted, are general data without specific pathologies.

\section{Methods}

Five databases were carefully examined: Latin American and Caribbean Health Sciences Literature (LILACS), Scientific Electronic Library Online (SciELO), Medical Literature Analysis and Retrieval System Online (MEDLINE / PubMed), Scopus and
Science Citation Index Expanded (Web of Science). The descriptors used were obtained in Descriptors of Health Sciences (DeHS) and Medical Subject Headings (MeSH).

Thus, the keywords were used in the Boolean operators, "and" and "or": temporomandibular joint disorders, temporomandibular joint disaese, epidemiology, incidence, prevalence, music, occupational diseases, neck pain, risk factors, musicians, pain. The review was conducted in August and in September 2015 and the search strategy in each base can be seen in Table 1.

Table 1 - Search strategy in electronic databases, Brasilia, 2016

\begin{tabular}{|c|c|c|c|}
\hline Data base & Key words & $\begin{array}{l}\text { Booleans } \\
\text { operators }\end{array}$ & $\begin{array}{l}\text { Obtained } \\
\text { references }\end{array}$ \\
\hline Medline/PubMed & $\begin{array}{l}\text { Temporomandibular joint disorders, temporomandibular joint disaese, epidemiology, } \\
\text { incidence, prevalence, music, occupational diseases, neck pain, risk factors, } \\
\text { musicians e pain }\end{array}$ & And/Or & 26 \\
\hline LILACS & $\begin{array}{l}\text { Temporomandibular joint disorders, temporomandibular joint disaese, epidemiology, } \\
\text { incidence, prevalence, music, occupational diseases, neck pain, risk factors, } \\
\text { musicians e pain }\end{array}$ & And/Or & 2 \\
\hline Scielo Brazil & $\begin{array}{l}\text { Temporomandibular joint disorders, temporomandibular joint disaese, epidemiology, } \\
\text { incidence, prevalence, music, occupational diseases, neck pain, risk factors, } \\
\text { musicians e pain }\end{array}$ & And/Or & 2 \\
\hline Scopus & $\begin{array}{l}\text { Temporomandibular joint disorders, temporomandibular joint disaese, epidemiology, } \\
\text { incidence, prevalence, music, occupational diseases, neck pain, risk factors, } \\
\text { musicians e pain }\end{array}$ & And/Or & 27 \\
\hline Web of Science & $\begin{array}{l}\text { Temporomandibular joint disorders, temporomandibular joint disaese, epidemiology, } \\
\text { incidence, prevalence, music, occupational diseases, neck pain, risk factors, } \\
\text { musicians e pain }\end{array}$ & And/Or & 25 \\
\hline Total Quotes & & & 82 \\
\hline
\end{tabular}

Selection Criteria: At first, the articles were selected only with the combination of descriptors, as described above. Subsequently, the abstracts of the articles were carefully read and from reading were selected those who met the following inclusion criteria: 1) articles that aimed to determine the prevalence of temporomandibular disorders and neck pain in musicians; 2) articles written in both Portuguese and English; 3) articles that were published in the last 10 years (2005 - 2015).

The flowchart of the search and selection of articles is shown in Figure 1.

STROBE score: In a third time, to check the quality of the studies found, the articles were read and evaluated by the the Strengthening the Reporting of Observational Studies in Epidemiology criteria (STROBE) (18). Each of the 22 criteria set out by the STROBE received a score of 0 or 1 and each article would receive a final score up to 22 points. Thus, the articles were analyzed and received or not the score according to the presence of STROBE criteria.

Later on, the percentage of scores obtained on each item to better assess their quality was calculated. And so, the authors defined that the articles which obtain a percentage above $50 \%$, in other words, those which had at least 11 of the 22 criteria would be considered good quality ones and could be part of this work analysis. In Table 2 are detailed scores of each item and its representation in percentage. 


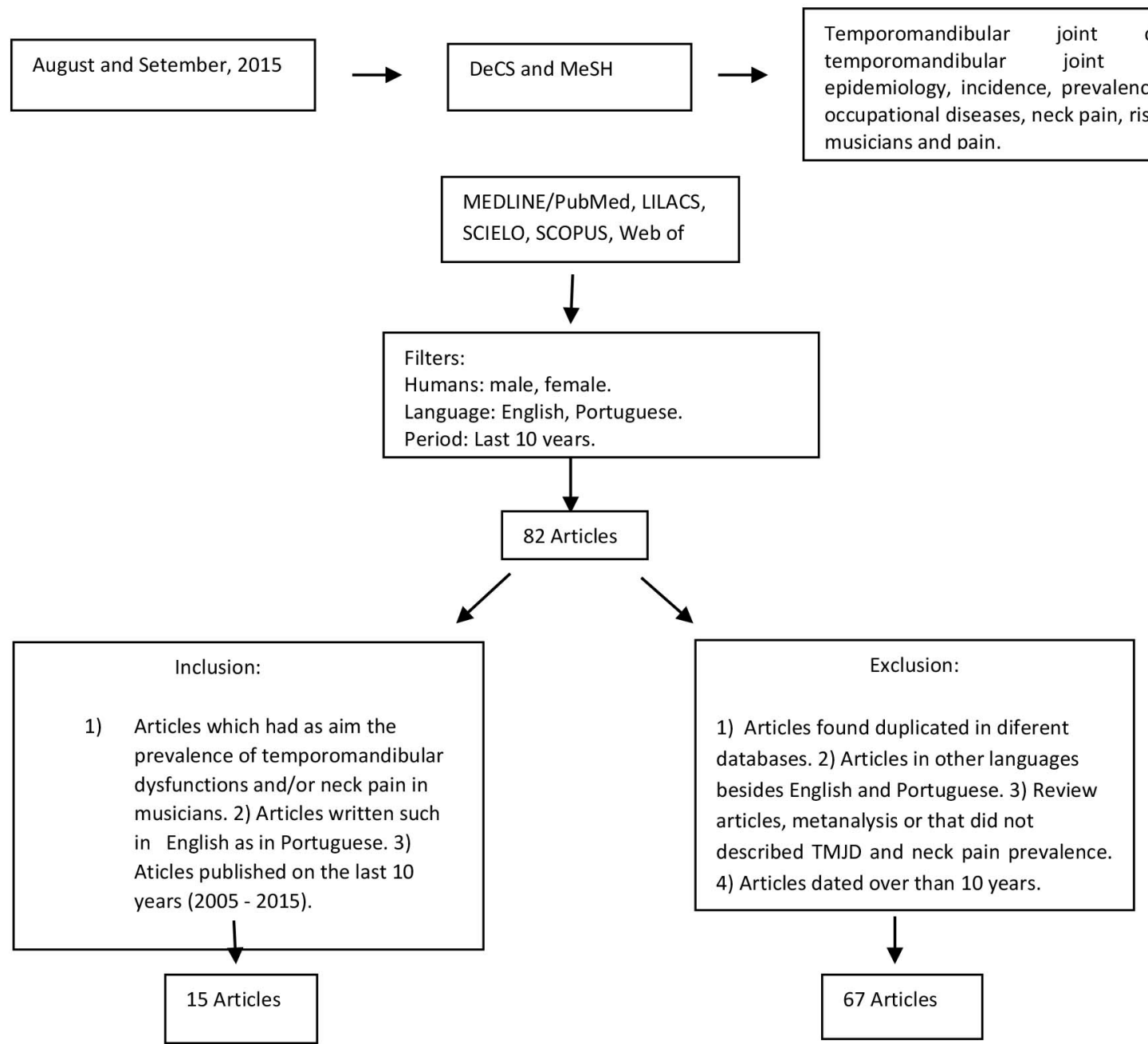

Figure 1 - Flowchart of search and selection of articles.

Table 2 - Score and quality percentage of articles from the STROBE criteria, Brasilia, 2016

\begin{tabular}{llcc}
\hline Reference & $\begin{array}{c}\text { Kind of } \\
\text { study }\end{array}$ & $\begin{array}{c}\text { Obtained } \\
\text { score }\end{array}$ & \% \\
\hline Paarup et al, 2011 (19) & Transversal & 21 & 95.4 \\
Nyman et al, 2007 (12) & Transversal & 19 & 86.3 \\
Abréu-Ramos et al., 2007 (20) & Transversal & 18 & 81.8 \\
Kok et al, 2013 (21) & Transversal & 18 & 81.8 \\
Dhrithi et al., 2013 (22) & Transversal & 18 & 81.8 \\
Paarup et al, 2012 (23) & Transversal & 18 & 81.8 \\
Stanhope et al, 2014 (24) & Transversal & 18 & 81.8 \\
Steinmetz et al, 2014 (25) & Transversal & 18 & 81.8 \\
Neto et al., 2009(15) & Transversal & 17 & 77.2 \\
Rodriguez Lozano et al. 2008 (26) & Transversal & 17 & 77.2 \\
Pampel et al, 2014 (27) & Transversal & 16 & 72.7 \\
Steinmetz et al, 2009 (28) & Transversal & 16 & 72.7 \\
Rodriguez Lozano et al, 2010 (29) & Transversal & 15 & 68.1 \\
Steinmetz et al, 2006 (30) & Transversal & 14 & 63.6 \\
Teixeira et al, 2015 (31) & Transversal & 12 & 54.5 \\
\hline
\end{tabular}

\section{Results}

About 15 of the selected articles met the inclusion criteria and had enough score, according to the STROBE. Table 3 shows the main findings of each of the 15 articles analyzed.

Among the selected studies to be part of this review, four were conducted in Germany, two in Brazil, two in Spain, two in Denmark. Australia, Netherlands, Puerto Rico, India and Sweden had only one study each. The age range of the sample participants ranged from 14 to 63 years.

As for the kind of played instrument, most of the articles evaluated instrumentalists interpreters of bowed string (violin, viola and cello) and wind instrumentalists (flute, piccolo, bassoon, oboe, clarinet, trumpet, trombone and tuba). Table 4 can be seen the instrumentalists percentage found in the studies by type of instrument run. 
Table 3 - Results of the described studies, Brasilia, 2016

\begin{tabular}{|c|c|c|c|c|}
\hline Reference & Country & Sample & Population & Results \\
\hline Abréu-Ramos et al.,2007 (20) & Puerto Rico & 82 & $\begin{array}{l}\text { Violin, viola, cello, contrabass, } \\
\text { wind instrument and } \\
\text { percussion players. }\end{array}$ & $\begin{array}{l}\text { About } 10 \% \text { of violinists and violists } \\
\text { related pain symptoms in the TMJ and } \\
64 \% \text { felt neck pain. }\end{array}$ \\
\hline Dhrithi et al., 2013 (22) & India & 66 & Electric guitar players. & About $29 \%$ reported neck pain. \\
\hline Kok et al., 2013 (21) & Netherlands & 87 & Music students. & $\begin{array}{l}\text { About } 34.8 \% \text { reported pain in the TMJ } \\
\text { and } 73.1 \% \text { in cervical. }\end{array}$ \\
\hline Nyman et al., 2007 (12) & Sweden & 250 & $\begin{array}{l}\text { Violin, viola, cello, contrabass, } \\
\text { flute, trumpet, trombone, } \\
\text { bassoon, clarinet, horn, oboe } \\
\text { and tuba. }\end{array}$ & $25.5 \%$ reported neck pain. \\
\hline Paarup et al., 2011 (19) & Denmark & 342 & $\begin{array}{l}\text { Violin, viola, cello, contrabass, } \\
\text { flute, clarinet, oboe, bassoon, } \\
\text { horn, trumpet, trombone, tuba } \\
\text { and percussion. }\end{array}$ & $80 \%$ reported neck pain. \\
\hline Paarup et al., 2012 (23) & Denmark & 441 & $\begin{array}{l}\text { Violin, viola, cello, contrabass, } \\
\text { flute, clarinet, oboe, bassoon, } \\
\text { horn, trumpet, trombone, tuba } \\
\text { and percussion. }\end{array}$ & $64.8 \%$ reported neck pain. \\
\hline Pampel et al., 2014 (27) & Germany & 102 & Wind instrument players. & $\begin{array}{l}86.2 \% \text { had joint sounds, } 100 \% \\
\text { showed some parafunction. }\end{array}$ \\
\hline Rodriguez-Lozano et al., 2008 (26) & Spain & 91 & Violinists. & $73 \%$ had bruxism. \\
\hline Rodriguez-Lozano et al., 2010 (29) & Spain & 91 & Violinists. & $\begin{array}{l}24.4 \% \text { with TMJ pain, } \\
29.3 \% \text { limitation of mouth opening, } \\
17.1 \% \text { had already locking or blocking } \\
\text { jaw, } 26.8 \% \text { had parafunctional habits, } \\
\text { and } 51.2 \% \text { had TMJ sounds. }\end{array}$ \\
\hline Stanhope et al., 2014 (24) & Australia & 14 & Wind instrument players. & $38 \%$ reported neck pain \\
\hline Stechman Neto, et al., 2009 (15) & Brazil & 92 & $\begin{array}{l}\text { Wind instrument Interpreters } \\
\text { (metals and reeds), violinists } \\
\text { and violists. }\end{array}$ & $\begin{array}{l}42.3 \% \text { have parafunction (bruxism } \\
\text { or clenching), } 25 \% \text { had TMJ pain, } \\
42 \% \text { reported TMJ sounds, } 40 \% \text { ear } \\
\text { fullness and } 35 \% \text { tinnitus. }\end{array}$ \\
\hline Steinmetz et al., 2006 (30) & Germany & 31 & Violinists. & $\begin{array}{l}45 \% \text { had TMJ pain, } 65 \% \text { pain in the } \\
\text { masticatory muscles, } 58 \% \text { wiht TMJ } \\
\text { noise. }\end{array}$ \\
\hline Steinmetz et al., 2009 (28) & Germany & 30 & $\begin{array}{l}\text { Violinists, pianists, cellists, } \\
\text { clarinetists, trombonists, } \\
\text { violists, pipers, flutists. }\end{array}$ & $\begin{array}{l}80 \% \text { had neck pain and } 63 \% \text { TMJ } \\
\text { pain. }\end{array}$ \\
\hline Steinmetz et al., 2014 (25) & Germany & 408 & $\begin{array}{l}\text { Violin, viola, cello, contrabass, } \\
\text { flute, clarinet, oboe, bassoon, } \\
\text { horn, trumpet, trombone, tuba, } \\
\text { percussion and piano. }\end{array}$ & $\begin{array}{l}\text { About } 81 \% \text { had TMJ pain, } 34 \% \text { had } \\
\text { bruxism or clenching the jaw. }\end{array}$ \\
\hline Teixeira et al., 2015 (31) & Brazil & 11 & Violists and violinists. & 72.7\% reported neck pain. \\
\hline
\end{tabular}


Table 4 - Percentage of instrumentalists by type of executed instrument, Brasilia, 2016

\begin{tabular}{ll}
\hline Instruments & $\%$ \\
\hline Violin/viola & 42 \\
Cello/ Contrabass & 12 \\
Wooden $^{1}$ & 26 \\
Metals $^{2}$ & 12 \\
Other $^{3}$ & 8 \\
\hline
\end{tabular}

Note: 1. Flauta, piccolo, Bassoon, Oboe and Clarinet, 2 Trumpet, Trombone and Tuba, 3. Piano. Guitar, Singers, Percussion and Harp.

In the studies it was found that the prevalence of TMJ pain ranged from $10-81 \%$, and in violin and viola musicians it ranged from $10-28 \%$. In the wind instruments musicians the change in prevalence was of $19-45 \%$.

Some studies have also evaluated the presence of parafunctional habits. In these studies it was observed that the prevalence of habits such as bruxism and teeth clenching ranged from 26.8 to $100 \%$ in all studied instrumentalists and in the wind interpreters the prevalence was of $34-100 \%$. Also in violinists was found a prevalence of parafunctional habits that ranged from 34 - 73\%.

Moreover, were also reported symptoms such as locking, joint noises, maximum mouth opening difficulty, ear fullness, tinnitus, masticatory muscles pain. The studies found, indicated the presence of mouth locking, indicating a symptom prevalence of $17 \%$. The prevalence of joint sounds ranged from 42 - 58\%.

Also the difficulty of maximum mouth opening with a prevalence of $29.3 \%$ was reported. The feeling of ear fullness was observed in studies with a prevalence of $40 \%$.

The tinnitus presence was reported with a 35\% prevalence. And the presence of pain in the masticatory muscles showed a $65 \%$ prevalence.

The prevalence of neck pain ranged from $29-80 \%$ in all studied instrumentalists and in violinists and violists it ranged from 36 - 80\%. Already in wind instruments musicians ranged from $38-45 \%$.

Among all the musicians surveyed the prevalence of TMJ pain ranged from $25-47 \%$ and the prevalence of neck pain ranged from $25-78 \%$.

Regarding the gender difference, the female instrumentalists had a higher prevalence of about $50 \%$ of neck pain, males showed a prevalence of $30 \%$ in comparison. It has been observed that women were 2.4 times more likely to report orofacial pain.

\section{Discussion}

In this study, it was observed that the musicians have both TMJD and neck pain, observing a significant prevalence, especially in violin, viola, and wind instrument (metal and wood) musicians. These findings have been substantiated in the literature by the need that the musician has to acquire the musical expertise. Thus, in order to master and refine the technique, the musician faces several hours of practice and testing, running movements repetitively and in postures, often anti-physiologic, specific to each instrument, which gives an important risk factor for the appearance of osteomyoarticular injury in general $(16,31)$.

When it is verified in particular in case of neck pain, identified in the present study, must be considered that this may be caused by the anti-physiologic postures mentioned in the literature, such as rotating the neck, anterior projection and head tilt and the static abduction posture with internal rotation of the right shoulder and external of the contralateral limb (14). Vicious posture as the shoulder protrusion for violin performance were also observed in previous studies. Such postures cause a trapezius distension and favors scapulohumeral pace disarrangement, which can contribute to cervical pain complaints in the studies participants instrumentalists found $(32-34)$. Another aspect that may be responsible for the prevalence of neck pain found in this study is the increased tension in trapezoid caused by the need of the violinist and violist to maintain the support of the $\operatorname{arch}(32-34)$.

In the case of the presence of TMJD symptoms, pointed out in studies that composed this work, these can be justified by the instrument support posture in the viola and violin case, which is held between the Parliament and the left shoulder, causing that the head remains in combined bending ipsilateral rotation during performance $(32-34)$. This positioning to support the violin between the chin and the shoulder has been highlighted in the literature as a factor that favors a mandibular deviation and an isometric contraction of the face muscles which favors an articulation shift of its physiological axis, without adequate stabilizing that can result in temporomandibular joint complaints $(32,33)$. 
The literature also adds that both violinists and violists as the wind instrumentalists perform the protrusion head $(32-34)$. The protrusion also puts the muscles and the rear fascia in permanent tension which can help, also cervical problems, as blood provision restrictions and appearance of nerve impingement that may impact on the structures of distal upper limb $(32$ - 34). This head position maintained for long hours associated with the instrument chin support, in the case of violin and viola, in instrumental practice favors the appearance of both TMJD and neck pain, according to the findings of this review $(13,35)$.

Regarding the prevalence of neck pain found in this study in wind instrument players, it can be highlighted that the presence of anti-physiologic postures as the foward projected head, the shoulders protrusion and internal rotation, confer risk factors like appearance of neck pain these professionals when compared to the violinist, as found in the literature (14). Authors state that the flute support, for example, is performed by a support point at the proximal phalange of the left hand index finger which presses the flute against the chin at the height of the piper lower lip (36). Another referenced point in literature is the right hand thumb that will press the flute in the opposite direction from the first point of support. These two forces have the function of balancing the instrument when the instrument is positioned between the flutist chin and the lower lip which favors an isometric trapezoidal region and upper limbs establishing the emergence of pains found in this study (36).

In addition, changes in temporomandibular joint can be caused in wind instruments because there is a muscular work required by the need to pump air through the nozzle. The literature suggests that there are different types of nozzles depending on the instrument. The trombone and trumpet have a mouthpiece like a cup in which the musician must force his lips. In the clarinet and saxophone the mouthpiece is between the lips that have to perform a sealing force so that the air does not escape with the support held at the bottom. In the flute the mouthpiece rests on the lower lip. In all cases the teeth can be affected, either by the nozzle pressure, the adjacent soft tissues or by the air column displaced, these could favor the appearance of occlusion problems, according to the literature (37).

It is added that specific training techniques for sound production. Through various nozzles, which is the position of the lips in a specific way to direct the air column against the nozzle, for producing bass, middle and treble, as well as control of pitch and vibrato, directly influences the complex work of the temporomandibular joint and may cause TMJD as found in this study (36).

In this aspect, it was noted in the literature that biomechanical work is required in wind instrument, not only when the player performs the training and support, but also in the air column production and in the head, neck and shoulders position. Furthermore, there are the trunk, arms, hands and lower limbs positioning and maintenance of a postural balance while holding the instrument during a performance $(35,36)$. These anti-physiologic postures are necessary for the instrumental technique, however, these postural arrangements lead to muscle fatigue and, later, to the emergence of acute injuries which may become chronic, what corroborates the findings of this study (38). Beyond this, some postures favor the appearance of parafunctional activity of the stomatognathic system, as they require from the jaw and orofacial structures an effort beyond the physiological, important finding also evident in the present work studies $(35,39)$.

The literature also points out that both the musicians performing wind instruments as the bowed string, like the violin and viola, the upper limb elevated position for longer than three hours can cause more complaints, signs and symptoms in the cervical region (12).

Another point that may explain the symptoms found in this study is that both the flute and the violin are instruments supported completely by the musician with isometric muscle strength for a long time during the performance, especially of the neck, shoulder girdle and upper limbs and requires a certain degree of trunk and neck asymmetry posture. These postures can contribute to the emergence of chronic misalignment, disturbance of the static, joint rigidities, compressions, muscle weakness and changes in fascias, contributing to the emergence of pain (36). Associated with this, the frequency of instrumental practice and the profession time also that have been directly related to the musculoskeletal complaints in such instrumentalist $(40,41)$.

Regarding gender differences, this study reports in the literature a higher prevalence of TMJD and neck pain in female musicians, as well as musculoskeletal complaints for all regions of the body when compared to male musicians. This difference may be caused by the presence of a lower muscle strength and a greater joint hypermobility of the females when compared 
to males (13). Associated with such factors the sex related hormones are also involved in pain perception, causing women to become more vulnerable to the symptoms (42).

Another point that favors the appearance of more constant pain in women than in men is also due to social issues of sexual division of housework. The literature reports that women generally have less time off work to activities that could shorten healthcare costs within their occupational activity (42).

Besides gender, the study showed researches where young instrumentalists also has pain complaints. The virtuosity charged in music conservatories has a direct impact on the osteomyoarticular structures of young professionals. Stringed instruments, like the violin, can influence the formation of craniofacial bones and the onset of malocclusion. The support of the instrument and the asymmetric position of the jaw combined with the intense practice can cause changes in the face growth of a young person, imbalances strength of the face muscle, causing joint pain during mastication, a stiffness feeling, teeth clenching, protrusion, muscle tension and deviation of the jaw (37).

Other instrumentalists, beyond the bowed string and wind instrumentalists, also had TMJD prevalence and neck pain found in this study, as in the case of pianists and eletric guitarists. A study that evaluated the electromyographic activity of the masseter and temporal during the instrument execution and found that the activity of these musculature was almost four times higher compared with chewing. This fact was attributed to physical and psychosocial demands of performance and virtuosity, to concentration increased levels, stress and anxiety during the pianist activity (43). For guitarists, literature justifies that to run the instrument there is a shoulder lifting generating a tension in the cervical spine, this posture sustained for long hours of instrumental practice gives risk factor for the forthcoming of neck pain $(44,45)$.

\section{Conclusion}

The articles presented in this study reported that musicians have TMJD and neck pain complaints, particularly the wind players and rubbed strings like the violin and the viola. The study also pointed out that the wind players have a tendency to experience more symptoms of temporomandibular disorders in relation to bowed string instruments players, and the neck pain symptoms are similar between the two types of instrumentalists.

These injuries are closely related to the requirements of the working musician, whether in work organization or, more prominent, in the anti-physiologic postures required in instrumental performance.

The proposed study aims to point the need to look at the musician as a worker who has profession advantages, but also the burden of overhead, unfortunately, a limitation of the study was the difficulty in finding population-based studies and that detailed the risk factors based on the movement biomechanics. Future reflections with larger populations could be developed, as well as studies based on biomechanical analyzes by type of instrument. In this context, this review aims to contribute to building reflections on the musician work and his demands required by their professional activity.

\section{References}

1. Lemos GA, Paulino MR, Forte FDS, Beltrão RTS, Batista AUD. Influence of temporomandibular disorder presence and severity on oral health-related quality of life. Rev Dor. 2015;16:10-4.

2. Thilander B, Rubio G, Pena L, Mayorga C. Prevalence of temporomandibular dysfunction and its association with malocclusion in children and adolescents: an epidemiologic study related to specified stages of dental development. Angle Orthod. 2002;72(2):146-54.

3. Tvrdy P. Methods of imaging in the diagnosis of temporomandibular joint disorders. Biomed Pap Med. 2007;151(1):133-6.

4. Leeuw R. Dor orofacial: guia de avaliação, diagnóstico e tratamento. 4th ed. São Paulo: Quintessence Nacional; 2010 .

5. Winocur E, Littner D, Adams I, Gavish A. Oral habits and their association with signs and symptoms of temporomandibular disorders in adolescents: a gender comparison. Oral Surg Oral Med Oral Pathol Oral Radiol Endod. 2006;102(4):482-7.

6. Figueiredo VMG, Cavalcanti AL, Farias ABL, Nascimento SR. Prevalência de sinais, sintomas e fatores associados em portadores de disfunção temporomandibular. Acta Sci Health Sci. 2009;31(2):159-63. 
7. Dworkin SF, Huggins K, Wilson L, Mancl L, Turner J, Massoth D, et al. A randomized clinical trial using research diagnostic criteria for temporomandibular disorders-axis II to target clinic cases for a tailored selfcare TMD program. J Orofac Pain. 2002;16(1):48-63.

8. Resende CM, Alves AC, Coelho LT, Alchieri JC, Roncalli AG, Barbosa GA. Quality of life and general health in patients with temporomandibular disorders. Braz Oral Res. 2013;27(2):116-21.

9. Moreno BG, Maluf SA, Marques AP. Avaliação clínica e da qualidade de vida de indivíduos com disfunção temporomandibular. Rev Bras Fisioter. 2009;13(3):210-4.

10. Oliveira AS, Bermudez CC, Souza RA, Souza CMF, Dias EM, Castro CES, et al. Impacto da dor na vida de portadores de disfunção temporomandibular. J Appl Oral Sci. 2003;11(2):138-43.

11. Faulin EF, Guedes CG, Feltrin PP, Joffiley CMMSC. Association between temporomandibular disorders and abnormal head postures. Braz Oral Res. 2015;29(1):1-6.

12. Nyman T, Wiktorin C, Mulder M, Johansson YL. Work Postures and Neck-Shoulder Pain Among Orchestra Musicians. Am J Ind Med. 2007;50(5):370-6.

13. Frank A, Von Muhlen CA. Queixas musculoesqueléticas em músicos: prevalência e fatores de risco. Rev Bras Reumatol. 2007;47(3):188-96.

14. Subtil MML, Bonomo LMM. Avaliação fisioterapêutica nos músicos de uma orquestra filarmônica. Per Musi. 2012;25:85-90.

15. Stechman Neto JS, Almeida C, Bradasch ER, Corteletti LCBJ, Silvério KC, Pontes MMA, et al. Ocorrência de sinais e sintomas de disfunção temporomandibular em músicos. Rev Soc Bras Fonoaudiol. 2009;14(3):362-6.

16. Oliveira CFC, Vezzá FMG. A saúde dos músicos: dor na prática profissional de músicos de orquestra no ABCD paulista. Rev Bras Saude Ocup. 2014;35(121):33-40.

17. Fragelli TBO, Günther IA. Relação entre dor e antecedentes de adoecimento físico ocupacional: um estudo entre músicos instrumentistas. Per Musi. 2009;19:18-23.

18. Malta M, Cardoso LO, Bastos FI, Magnanini MMF, Silva CMFP. Iniciativa STROBE: subsídios para a comunicação de estudos observacionais. Rev Saude Publica. 2010;44(3):559-65.
19. Paarup HM, Baelum J, Holm JW, Manniche C, Wedderkopp N. Prevalence and consequences of musculoskeletal symptoms in symphony orchestra musicians vary by gender: a cross-sectional study. BMC Musculoskelet Disord. 2011;12:223.

20. Abréu-Ramos AM, Micheo WF. Lifetima Prevalence of Upper-body Musculoskeletal Problems in a Professional-Level Symphony Orchestra: Age, Gender, and Instrument-specific Results. Med Probl Perform Art. 2007;22(3):97-104.

21. Kok LM, Vlieland TP, Fiocco M, Nelissen RG. A comparative study on the prevalence of musculoskeletal complaints among musicians and non-musicians. BMC Musculoskelet Disord. 2013;14:9.

22. Dhrithi MA, Agrawal PR, Aju K. Prevalence of playing-related musculoskeletal disorder (prmsd) among amateur young guitar players. J Musculoskelet Res. 2013;16(2):133-8.

23. Paarup HM, Baelum J, Manniche C, Holm JW, Wedderkopp N. Occurrence and co-existence of localized musculoskeletal symptoms and findings in work-attending orchestra musicians - an exploratory crosssectional study. BMC Res Notes. 2012;5:541.

24. Stanhope J, Milanese S, Grimmer K. University woodwind students' experiences with playing-related injuries and their management: a pilot study. J Pain Res. 2014;7:133-48.

25. Steinmetz A, Zeh A, Delank KS, Peroz I. Symptoms of craniomandibular dysfunction in professional orchestra musicians. Occupat Medicine. 2014;14(64):17-22.

26. Lozano FJR, Yuguero MRS, Fenoll AB. Bruxism Related to Violin Playing. Med Probl Perform Art. 2008;23:12-5.

27. Pampel M, Jakstat HA, Ahlers OM. Impact of sound production by wind instruments on the temporomandibular system of male instrumentalists. Work. 2014;48(1):27-35.

28. Steinmetz A, Ridder PH, Methfessel G, Muche B. Professional musicians with craniomandibular dysfunctions treated with oral splints. Cranio. 2009;27(4):221-30.

29. Rodríguez-Lozano FJ, Sáez-Yuguero MR, BermejoFenoll A. Prevalence of temporomandibular disorderrelated findings in violinists compared with control subjects. Oral Surg Oral Med Oral Pathol Oral Radiol Endod. 2010;109(1):e15-9. 
30. Steinmetz A, Ridder PH, Reichelt A. Craniomandibular Dysfuntion and Violin Playing: Prevalence and Influence of Oral Splints on Head and Neck Muscles in Violinists. Med Probl Perform Art. 2006;21:183-9.

31. Teixeira CS, Andrade RD, Kothe F, Felden ÉPG. Prática instrumental e desconforto corporal: um estudo com músicos de violino e viola. Mundo Saude. 2015;39(1):43-53.

32. Alves CV. Padrões físicos inadequados na performance musical de estudantes de violino [master's thesis]. Belo Horizonte (Brazil): Universidade Federal de Minas Gerais; 2008. Portuguese.

33. Alves CV. Avaliação fisioterápica de alunos de violino durante performance musical - análise dos diagnósticos cinesiológicos e biomecânicos mais encontrados. Modus. 2011;6(8):71-88.

34. Costa C, Abrahão J. Quando o tocar dói: um olhar ergonômico sobre o fazer musical. Per Musi. 2004;10:60-79.

35. Frias-Bulhosa J. Impactos oro-faciais associados à utilização de instrumentos musicais. Rev Port Estomatol Med Dent Cir Maxilofac. 2012;53(2):108-16.

36. Fonseca MPM, Cardoso F, Guimarães A. Fundamentos biomecânicos da postura e suas implicações na performance da flauta. Per Musi. 2015;31:86-107.

37. Głowacka A, Matthews-Kozanecka M, Kawala M, Kawala B. The impact of the long-term playing of musical instruments on the stomatognathic system review. Adv Clin Exp Med. 2014;23(1)143-6.

38. Freitas DCV, Marques K. Prevalência da disfunção temporomandibular em violinistas e violistas da orquestra petrobras sinfonica. Rev Novo Enfoque. 2010;10:58-67.
39. Lacerda FAO. Estudo da prevalencia de desordens temporomandibulares em músicos de sopro [master's thesis]. Porto (Portugal): Universidade Fernando Pessoa; 2011. Portuguese.

40. Mehrparvar AH, Mostaghaci M, Gerami RF. Musculoskeletal disorders among Iranian instrumentalists. Med Probl Perform Art. 2012;27(4):193-6.

41. Ackermann B, Driscoll T, Kenny DT. Musculoskeletal pain and injury in professional orchestral musicians in Australia. Med Probl Perform Art. 2012;27(4):181-7.

42. Strazdins L, Bammer G. Women, work and musculoskeletal health. Soc Sci Med. 2004;58(6):997-1005.

43. Lourenço S, Clemente M, Coimbra D, Barbosa AJP. Do pianists play with their Teeth? International Symposium on Performance Science; 2009 Dec 15-18; Auckland, New Zealand. Utrecht, The Netherlands: European Association of Conservatoires (AEC); 2009. p. 501-6.

44. Ranelli S, Straker L, Smith A. Playing-related musculoskeletal problems in children learning instrumental music: The association between problem location and gender, age, and music exposure factors. Med Probl Perform Art. 2011;26(3):123-39.

45. Ariëns GA, Bongers PM, Douwes M, Miedema MC, Hoogendoorn WE, Van der Wal G, et al. Are neck flexion, neck rotation, and sitting at work risk factors for neck pain? Results of a prospective cohort study. Occup Environ Med. 2001;58(3):200-7.

Received in $10 / 27 / 2015$ Recebido em 27/10/2015

Approved in 08/18/2016 Aprovado em 18/08/2016 